\title{
Upaya Meningkatkan Karakter Disiplin Anak Melalui Pohon Kedisiplinan di Tk IK Keluarga Ceria Sleman
}

\author{
Rizqiyyatunnisa \\ STPI Bina Insan Mulia Yogyakarta \\ Jl. Jembatan Merah No. 116 K, Prayan Kulon Condongcatur Depok Sleman \\ qiqinisa586@gmail.com
}

Naskah diterima: 26 Desember 2019, direvisi: 20 Maret 2020, diterbitkan: 31 Maret 2020

\begin{abstract}
Abstrak
Latar belakang masalah pada penelitian ini adalah Perilaku disiplin belum sepenuhnya dimiliki oleh anak, sehingga berakibat mempengaruhi proses kegiatan belajar mengajar di kelas. Perlu adanya pembaharuan berupa strategi atau media yang dapat membiasakan perilaku disiplin anak, agar anak dapat terbiasa untuk disiplin dengan menggunakan pohon kedisiplinan. Penelitian ini bertujuan untuk mengetahui penerapan "Pohon Kedisiplinan" dalam meningkatkan karakter disiplin anak dan untuk mengukur peningkatan karakter disiplin anak melalui "Pohon Kedisiplinan di TK IK Keluarga Ceria Sleman. Metode penelitian yang digunakan adalah metode penelitian dengan pendekatan kualitatif dalam bentuk penelitian tindakan kelas (PTK). Pengumpulan data dilakukan dengan observasi, wawancara, dan dokumentasi. Subjek dalam penelitian ini yaitu anak-anak Kelas B1 TK IK Keluarga Ceria Sleman dengan jumlah siswa 22 anak, yang terdiri dari 9 anak perempuan dan 13 anak laki-laki. Hasil penelitian ini dapat disimpulkan bahwa: 1) penerapan pohon kedisiplinan dilakukan dengan cara memperkenalkan pohon kedisiplinan, fungsinya dan cara menggunakannya pada anak, kemudian anak diminta untuk mencoba dan menerapkannya pada saat kegiatan pembelajaran. Guru mengamati sikap disiplin anak ketika menggunakan pohon kedisiplinan.; 2) peningkatan karakter disiplin anak melalui Pohon Kedisiplinan di TK IK Keluarga Ceria sebesar 39.7\%
\end{abstract}

Kata kunci: Anak, Disiplin, Karakter, Kualitatif, Pendidikan

\section{Abstract}

The background of the problem in this study is that the behavior of the discipline is not fully owned by the children, so that it affects the teaching and learning process in the classroom. There needs to be a renewal in the form of strategies or media that can familiarize the discipline behavior of children, so that children can get used to discipline by using the discipline tree. This study aims to determine the application of the "Disciplinary Tree" in improving the character of child discipline and to measure the increase in the character of child discipline through "Disciplinary Trees in Kindergarten IK Ceria Family Sleman. The research method used is a research method with a qualitative approach in the form of classroom action research (CAR). Data 
collection is done by observation, interviews, and documentation. The subjects in this study were children of Class B1 Kindergarten IK IK Ceria Sleman Family with a total of 22 students, consisting of 9 girls and 13 boys. The results of this study can be concluded that: 1) the application of the discipline tree is done by introducing the discipline tree, its function and how to use it in children, then the children are asked to try and apply it during the learning activities. The teacher observes the child's disciplined attitude when using the discipline tree; 2) increasing the character of child discipline through Disciplinary Trees at IK IK Ceria Happy Family by 39.7\%

Keywords: Children, Discipline, Character, Qualitative, Education

\section{Pendahuluan}

Saat ini banyak orangtua yang mengerti tentang pentingnya kedisiplinan, namun sebagian dari mereka belum menerapkan pembiasaan untuk berperilaku disiplin kepada anak mereka. Kedisiplinan merupakan hal yang wajib dibiasakan pada anak sejak dini. Pentingnya pembiasaan perilaku disiplin ini berguna untuk membentuk wataknya secara sehat, agar anak dapat mengembangkan hidupnya di kemudian hari dengan kreatif dan dinamis.

Pentingnya berperilaku disiplin di sekolah juga masih kurang dibiasakan, terutama pada lembaga Pendidikan Anak Usia Dini. Hal tersebut terlihat ketika anak berangkat kesiangan, terlambat menyelesaikan tugas di kelas, lupa waktu saat bermain, dan sebagainya yang sangat berpengaruh pada proses kegiatan belajar mengajar. Kegiatan belajar mengajar menjadi kurang maksimal yang pada akhirnya dapat berpengaruh pada perkembangan anak dan hasil belajar.

Pada lembaga Pendidikan Anak Usia dini hal tersebut masih di anggap lumrah bagi sebagian orangtua. Mereka tidak memperdulikan anaknya masuk sekolah dengan tertib atau tidak, mau memperhatikan gurunya atau tidak dan mau mentataati aturan sekolah atau tidak. Bahkan ada orangtua dengan santainya mengantarkan anaknya yang datang terlambat dengan alasan "yang penting anak mau berangkat sekolah". Hal tersebut perlu ditindak lanjuti agar pembiasaan perilaku disiplin dapat diberikan sejak anak usia dini.

Kurangnya perilaku disiplin yang dibiasakan pada anak usia dini akan memiliki pengaruh yang kurang baik ketika anak dewasa nanti. Anak akan terbiasa dengan pembiasaan tidak disiplin. Ketika dirumah dampaknya anak akan menentang setiap perkataan orangtuanya. Ketika di sekolah dampaknya anak akan lebih suka mengabaikan gurunya daripada memperhatikan pelajaran yang disampaikan. Ketika dimasyarakat 
dampaknya anak akan lebih suka melakukan kegiatan yang kurang bermanfaat dan cenderung merusak.

Dengan dampak tersebut maka perilaku disiplin wajib dibiasakan pada anak sejak usia dini. Hal tersebut dapat dilakukan dengan hal-hal kecil yang dibiasakan oleh orangtua dirumah, kemudian disekolah dikuatkan lagi oleh guru-gurunya. Sehingga kedepannya dimasyarakat ia akan menjadi orang yang suka melakukan kegiatan yang bermanfaat untuk banyak orang.

Berdasarkan hasil pengamatan yang peneliti amati, pembiasaan yang ditanamkan di lembaga TK Islam Kreatif Keluarga belum sepenuhnya dapat dirasakan manfaatnya. Perilaku disiplin belum sepenuhnya dimiliki oleh anak-anak. Saat ini masih ada anak yang datang terlambat dari jadwal yang telah ditetapkan sekolah, banyak anak yang bermain ketika guru menerangkan, banyak anak yang mengulur-ulur waktu ketika mengerjakan tugas, dan masih ada anak yang lupa waktu saat bermain ditaman / diluar kelas. Sehingga akibatnya sangat berpengaruh pada proses kegiatan belajar mengajar di kelas. Perlu adanya pembaharuan berupa strategi atau media yang dapat membiasakan perilaku disiplin anak, agar anak dapat terbiasa untuk disiplin dimanapun dan saat kegiatan apapun.

Berdasarkan permasalahan yang terjadi di TK Islam Kreatif Keluarga tersebut peneliti berupaya untuk mengetahui secara langsung strategi pembelajaran dengan memanfaatkan "Pohon Kedisiplinan" dalam upaya meningkatkan perilaku disiplin anak. Diharapkan dari penelitian ini dapat memperbaiki kondisi kegiatan belajar mengajar di TK Islam Kreatif Keluarga. Cara ini dianggap mampu memecahkan masalah diatas karena anak akan diajak untuk terbiasa bersikap disiplin dengan pembiasaan yang dilakukan secara teratur setiap hari melalui "Pohon Kedisiplinan".

Dengan "Pohon Kedisiplinan" ini anak akan terbiasa untuk selalu berangkat tepat waktu, menyelesaikan tugas dengan baik, mendengarkan guru saat pembelajaran dan menataati aturan yang telah disepakati. Sehingga dengan demikian akan muncul kebiasaan untuk selalu disiplin pada setiap kegiatan yang dilakukannya, baik disekolah ataupun dirumah.

\section{Metode penelitian}

Pendekatan yang digunakan dalam penelitian ini adalah metode kualitatif dalam bentuk penelitian tindakan kelas, dimana pendekatan kualitatif dalam bentuk PTK dalam penelitian ini adalah suatu penelitian yang digunakan untuk memperbaiki suatu proses 
belajar mengajar dengan kondisi objek yang alamiah dalam bentuk tindakan-tindakan yang dimunculkan dalam kelas, sehingga tercapainya tujuan untuk meningkatkan karakter disiplin anak melalui pohon kedisiplinan di TK IK Keluarga Ceria.

1. Setting dan Jadwal Penelitian

PTK ini dilakukan di Kelas B1 TK IK Keluarga Ceria. TK ini terletak di Jl. Parasamya No 7A Beran Lor 05/22 Tridadi Sleman atau sebelah utara Masjid Agung Dr. Wahidin Sudirohusodo komplek Pemkab Sleman, selama dua bulan dari bulan Juli sampai September, secara terperinci jadwal penelitian ini dapat diuraian dalam tabel III sebagai berikut:

Tabel II. JadwaldanKegiatanPenelitian

\begin{tabular}{|c|c|c|c|c|c|c|c|c|c|c|c|c|c|}
\hline \multirow[t]{2}{*}{$\mathbf{N}$} & \multirow{2}{*}{ Kegiatan } & \multicolumn{4}{|c|}{ Juli } & \multicolumn{4}{|c|}{ Agustus } & \multicolumn{4}{|c|}{$\begin{array}{c}\text { Septembe } \\
\text { r }\end{array}$} \\
\hline & & 1 & 2 & 3 & 4 & 1 & 2 & 3 & 4 & 1 & 2 & 3 & 4 \\
\hline 1 & $\begin{array}{l}\text { Persiapan dan penyusunan } \\
\text { proposal }\end{array}$ & & & & & & & & & & & & \\
\hline 2 & $\begin{array}{l}\text { Menyiapkan instrument } \\
\text { penelitian }\end{array}$ & & & & & & & & & & & & \\
\hline 3 & Pengumpulan data & & & & & & & & & & & & \\
\hline 4 & Analisis data & & & & & & & & & & & & \\
\hline 5 & Penyusunan laporan & & & & & & & & & & & & \\
\hline
\end{tabular}

2. Subyek Penelitian

Secara Spesifik PTK dilakukan dikelas B1, kelas ini terdiri dari 13 anak laki-laki dan 9 anak perempuan. Kelas ini dilengkapi dengan sarana prasarana yang terdiri dari berbagai macam APE indoor seperti : alat tulis, perlengkapan menggambar, perlengkapan meronce, beragam gambar tempelan dinding, kartu, puzzle, balok, dan sebagainya. Semua sarana prasarana tersebut digunakan secara efektif dalam pembelajaran sesuai dengan tema-tema tertentu.

3. Prosedur Penelitian

Prosedur PTK dalam penelitian ini mengikuti pendapat Suyadi yang menyatakan bahwa prosedur melakukan PTK terdiri dari empat tahap, yakni perencanaan, 
pelaksanaan, pengamatan dan Refleksi. Dari hasil Refleksi siklus I selanjutnya akan digunakan untuk perencanaan siklus II dengan tahapan yang sama.

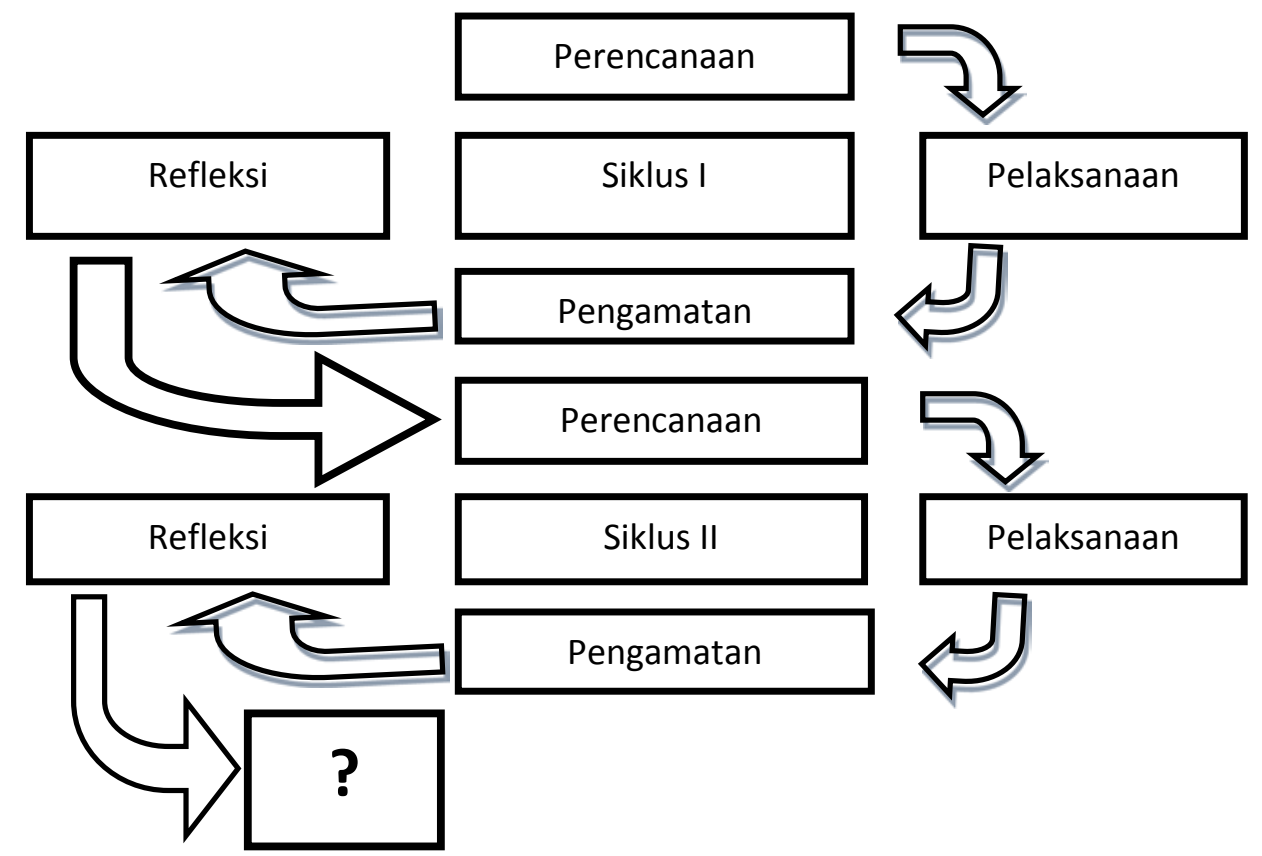

Gambar I. Alur Penelitian Tindakan Kelas

4. Teknik Pengumpulan data

Untuk mempermudah dalam penelitian ini peneliti menggunakan berbagai metode, metode yang digunakan yaitu :

a. Wawancara

Wawancara adalah metode pengambilan data dengan cara menanyakan sesuatu kepada seseorang yang menjadi informan atau responden. Wawancara digunakan sebagai teknik pengumpulan data apabila peneliti ingin melakukan studi pendahuluan untuk menemukan permasalahan yang harus di teliti, dan juga apabila peneliti ingin mengetahui hal-hal dari responden yang lebih mendalam dan jumlah respondennya sedikit/kecil. ${ }^{1}$ Dalam penelitian ini wawancara digunakan untuk menggali informasi lebih detail mengenai kedisiplinan anak, media yang digunakan, cara yang digunakan, hingga tindak lanjut yang telah dilakukan secara keseluruhan baik dikelas B1 khususnya maupun di TK Islam Kreatif Keluarga Ceria keadaan sekolah umumnya.

b. Observasi

Sutrisno Hadi mengemukakan bahwa, observasi merupakan suatu proses yang kompleks, suatu proses yang tersusun dari berbagai proses biologis dan psikologis.

${ }^{1}$ Sugiyono, Metode Penelitian Pendidikan, (Bandung: Alfabeta, 2014),hlm.194 
Dua di antara yang terpenting adalah proses-proses pengamatan dan ingatan. ${ }^{2}$ Kegiatan ini dilakukan untuk memperoleh data dari sekolah secara menyeluruh yang berkaitan dengan bagaimana kegiatan pembelajaran di kelas, bagaimana tingkat kedisiplinan anak, bagaimana karakteristik anak, sehingga dapat menentukan media apa yang cocok untuk diterapkan pada anak.

c. Dokumentasi

Cara lain untuk mengumpulkan data yaitu dengan menggunakan metode dokumentasi. Cara ini dilakukan dengan cara mencari informasi-informasi dari berbagai sumber tertulis, dokumen yang ada pada responden, dan keadaan lingkungan sekolah.

5. Analisis Data

Analisis data merupakan upaya yang dilakukan dengan cara memilih data yang penting untuk dipelajari dan memutuskan apa yang perlu disampaikan kepada orang lain. Untuk mengetahui ketuntasan belajar dapat dihitung dengan menggunakan rumus berikut ini :

$P=\frac{f}{n} x 100 \%$

Keterangan :

P : Prosentase

f : Jumlah anak hasil observasi

n : Jumlah sampel seluruh anak

100\% : Bilangan konstanta.

\section{Hasil dan Diskusi}

Penerapan Pohon Kedisiplinan dilakukan dengan langkah-langkah sebagai berikut :

1. Guru menyiapkan Rencana Penialaian Pembelajaran Harian (RPPH), alat dan bahan yang digunakan.

2. Pembukaan Pembelajaran

Guru membuka pembelajaran dengan salam dan do'a bersama, kemudian guru memberi motivasi dan membangun semangat serta antusias anak dengan beryanyi, tepuk dan bercerita.

\footnotetext{
${ }^{2}$ Ibid, hlm. 203
} 
3. Guru memperkenalkan pohon kedisiplinan pada anak dan menjelaskan kepada anak fungsi dari Pohon Kedisiplinan.

4. Guru menjelaskan bagaimana cara penggunaan pohon kedisiplinan pada anak, caranya yaitu:

a. Ketika diterapkan untuk mengukur ketepatan waktu anak berangkat ke sekolah, yaitu saat anak berangkat sekolah anak datang kemudian langsung mencari gantungan namanya sendiri kemudian gantungan nama tersebut di gantungkan pada pohon kedisiplinan.

b. Ketika diterapkan untuk mengukur kedisiplinan anak saat kegiatan belajar yaitu: sebelum belajar dimulai anak diberi penjelasan bahwa siapa saja yang dapat menyelesaikan tugasnya terlebih dahulu dengan baik dan benar maka anak tersebut dapat menggantungkan gantungan namanya pada pohon kedisiplinan.

c. Setelah itu guru memberikan kesempatan pada anak satu persatu untuk mencoba mempraktikkan cara menggunakan pohon kedisiplinan, dari mulai mencari gantungan namanya masing-masing sampai menggantungkannya pada pohon kedisiplinan.

5. Guru dapat menguji cobakannya kepada anak-anak dengan mempraktikkan langsung penerapan pohon kedisiplinan pada anak dan guru menjelaskan tugastugas yang harus mereka selesaikan.

6. Guru dapat mengevaluasi dan mengobservasi tingkat kedisiplinan anak saat anak menyelesaikan kegiatan.

7. Ketika anak telah selesai mengerjakan tugas dan sudah menggantungkan gantungan namanya pada pohon kedisiplinan, guru dapat memberikan evaluasi kegiatan hari ini dengan pohon kedisiplinan.

8. Guru memberikan apresiasi kepada anak tentang sikap-sikap disiplin yang sudah mereka tunjukkan hari itu.

9. Guru memberikan pesan-pesan untuk besok pagi ketika sampai di sekolah, untuk tidak lupa menggantungkan gantungan namanya di Pohon Kedisiplinan, agar bisa tau siapa saja yang sudah berangkat dan siapa saja yang belum berangkat.

10. Guru menutup pembelajaran dengan do’a bersama dan salam, serta memberikan pesan-pesan sikap kedisiplinan yang harus dilakukan di rumah. 


\section{Peningkatan karakter disiplin anak melalui "Pohon Kedisiplinan" di TK Islam Kreatif Keluarga Ceria Sleman Yogyakarta tahun ajaran 2018/2019}

Dalam penelitian ini, telah dilaksanakan proses penelitian selama 2 siklus. Setiap siklus terdapat 4 tahap dalam melaksanakan proses penelitian, yaitu : 1) perencanaan; 2) pelaksanaan tindakan; 3) pengamatan; 4) refleksi. Keempat tahap tersebut dapat dilihat pada deskripsi berikut ini.

\section{Perencanaan}

Guru menyiapkan Rencana Pelaksanaan Pembelajaran Harian (RPPH), lembar observasi, pohon kedisiplinan dan alat bahan pembelajaran yang akan digunakan sebelum melakukan kegiatan pembelajaran.

\section{Pelaksanaan Tindakan}

Kegiatan pra tindakan dilaksanakan pada hari Kamis 28 Juli 2018, siklus I pada hari Rabu dan Kamis tanggal 29 dan 30 Agustus 2018, serta siklus II dilaksanakan pada hari Selasa dan Rabu tanggal 4 dan 5 September 2018. Pelaksanaan tindakan ini dimulai dari kegiatan pembukaan hingga penutup di dalam kelas B1 dengan jumlah total 22 anak.

Pada kegiatan pra tindakan guru hanya mengamati anak-anak dan pendokumentasian saja tanpa ikut serta memberikan materi pembelajaran. Pada siklus I guru mulai memperkenalkan pohon kedisiplinan pada anak dan menggunakannya pada pembelajaran tanpa ada patokan nomor urut pada pohon, sehingga anak bebas menggangtungkan gantungan namanya pada pohon kedisiplinan.

Saat siklus II guru memberikan nomor pada pohon kedisiplinan, yang semula tidak ada nomornya untuk lebih menarik minat anak dalam menyelesaikan tuganya di kelas. Sehingga anak menjadi lebih semangat dalam mengerjakan tugas mereka.

\section{Observasi}

Saat melaksanakan penelitian guru melaksanakan pengamatan atau observasi terhadap kedisiplian anak di kelas B1, dan sebelum melakukan tindakan guru mengamati anak pada kegiatan pra tindakan yangmemperoleh data seperti berikut

Tabel III.

Prosentase Hasil Kedisiplinan Tahap Pra Tindakan

\begin{tabular}{|c|c|c|c|c|c|c|}
\hline $\mathbf{N}$ & \multirow{2}{*}{ Indikator Penilaian } & \multicolumn{4}{|c|}{ Hasil } & Jumla \\
\hline $\mathbf{o}$ & & $*$ & ** & $* * *$ & $* * * *$ & h Anak \\
\hline 1. & Masuk kelas tepat & $18.1 \%$ & $27,2 \%$ & $45,5 \%$ & $9,1 \%$ & $100 \%$ \\
\hline
\end{tabular}




\begin{tabular}{|c|l|c|c|c|c|c|}
\hline & waktu & & & & & $\begin{array}{l}\text { Mengerjakan tugas } \\
\text { dengan baik }\end{array}$ \\
\hline 3 & $\begin{array}{l}\text { Menyelesaikan tugas } \\
\text { tepat waktu }\end{array}$ & $18,1 \%$ & $18,1 \%$ & $54,5 \%$ & $9,1 \%$ & $100 \%$ \\
\hline 4 & $\begin{array}{l}\text { Tertib dalam } \\
\text { mengikuti } \\
\text { pembelajaran }\end{array}$ & $18,1 \%$ & $22,7 \%$ & $45,5 \%$ & $15,6 \%$ & $100 \%$ \\
\hline \multicolumn{7}{|l|}{ Rata-rata } \\
\hline
\end{tabular}

Dari data pada tahap pra tindakan tersebut kemudian guru melakukan tindakan pada siklus I.Pada Siklus I tingkat kedisiplinana anakmengalami peningkatan,untuk lebih lengkapnya dapat dilihat pada tabel dibawah ini :

Tabel IV.

\section{Prosentase Hasil Pembelajaran Siklus I}

\begin{tabular}{|c|c|c|c|c|c|c|}
\hline \multirow{2}{*}{ No } & \multirow{2}{*}{ Indikator Penilaian } & \multicolumn{4}{|c|}{ Hasil } & \multirow{2}{*}{$\begin{array}{c}\text { Jumlah } \\
\text { Anak }\end{array}$} \\
\hline & & * & $* *$ & $* * *$ & $* * * *$ & \\
\hline 1. & $\begin{array}{l}\text { Masuk kelas tepat } \\
\text { waktu }\end{array}$ & $0 \%$ & $18.2 \%$ & $19.1 \%$ & $22.7 \%$ & $100 \%$ \\
\hline 2. & $\begin{array}{l}\text { Mengerjakan tugas } \\
\text { dengan baik }\end{array}$ & $0 \%$ & $9.1 \%$ & $59.9 \%$ & $31.8 \%$ & $100 \%$ \\
\hline 3 & $\begin{array}{l}\text { Menyelesaikan tugas } \\
\text { tepat waktu }\end{array}$ & $0 \%$ & $13.6 \%$ & $63.6 \%$ & $22.7 \%$ & $100 \%$ \\
\hline 4 & $\begin{array}{l}\text { Tertib dalam } \\
\text { mengikuti } \\
\text { pembelajaran }\end{array}$ & $0 \%$ & $18.1 \%$ & $54.5 \%$ & $27.5 \%$ & $100 \%$ \\
\hline & Rat & & & & $26.1 \%$ & \\
\hline
\end{tabular}

Diperoleh peningkatan kedisiplinan yang semula dari tindakan pra siklus rata-rata sebesar 11,4\% menjadi 26,1\% pada siklus I. Peningkatan tersebut dinilai belum mencapai target yang diharapkan sehingga guru melakukan tahapan ke siklus II. Pada siklus II diperoleh data sebagai berikut: 
Tabel V.

Prosentase Hasil Pembelajaran Siklus II

\begin{tabular}{|c|l|c|c|c|c|c|}
\hline \multirow{2}{*}{ No } & \multirow{2}{*}{ Indikator Penilaian } & \multicolumn{4}{|c|}{ Hasil } & Jumlah \\
\cline { 3 - 5 } & $*$ & $* *$ & $* * *$ & $* * * *$ & Anak \\
\hline 1. & $\begin{array}{l}\text { Masuk kelas tepat } \\
\text { waktu }\end{array}$ & $0 \%$ & $0 \%$ & $45.4 \%$ & $63.6 \%$ & $100 \%$ \\
\hline 2. & $\begin{array}{l}\text { Mengerjakan tugas } \\
\text { dengan baik }\end{array}$ & $0 \%$ & $0 \%$ & $54.5 \%$ & $45.5 \%$ & $100 \%$ \\
\hline 3 & $\begin{array}{l}\text { Menyelesaikan tugas } \\
\text { tepat waktu }\end{array}$ & $0 \%$ & $0 \%$ & $50 \%$ & $50 \%$ & $100 \%$ \\
\hline 4 & $\begin{array}{l}\text { Tertib dalam mengikuti } \\
\text { pembelajaran }\end{array}$ & $0 \%$ & $0 \%$ & $54.5 \%$ & $45.4 \%$ & $100 \%$ \\
\hline \multicolumn{4}{|c|}{ Rata-rata } \\
\hline
\end{tabular}

Dari data diatas tingkat kedisiplinana anak mengalami peningkatan yang cukup baik. Yang semula pada siklus I sebesar 26,1\% menjadi 51,1\% pada siklus II, karena peningkatan sudah sesuai dengan yang diharapkan, sehingga dinilai tidak perlu diadakan tindakan selanjutnya.

Peningkatan dari kedisiplinan anak dari Pra tindakan hingga Siklus II dapat dikelompokkan menjadi data pada tabel dibawah ini :

Tabel VI.

Prosentase Perbandingan Hasil Pembelajaran dari Kegiatan Pra Tindakan hingga Siklus II

\begin{tabular}{|c|l|c|c|c|c|}
\hline \multirow{2}{*}{ No } & \multirow{2}{*}{$\begin{array}{c}\text { Indikator } \\
\text { Penilaian }\end{array}$} & $\begin{array}{c}\text { Pra } \\
\text { Tindakan }\end{array}$ & $\begin{array}{c}\text { Siklus } \\
\text { I }\end{array}$ & $\begin{array}{c}\text { Siklus } \\
\text { II }\end{array}$ & Peningkatan \\
\cline { 3 - 6 } 1. & $\begin{array}{l}\text { Masuk kelas tepat } \\
\text { waktu }\end{array}$ & $9.1 \%$ & $22.7 \%$ & $63.5 \%$ & $54.4 \%$ \\
\hline 2. & $\begin{array}{l}\text { Mengerjakan } \\
\text { tugas dengan baik }\end{array}$ & $13.6 \%$ & $31.8 \%$ & $45.5 \%$ & $31.9 \%$ \\
\hline 3 & $\begin{array}{l}\text { Menyelesaikan } \\
\text { tugas tepat waktu }\end{array}$ & $9.1 \%$ & $22.7 \%$ & $50 \%$ & $40.9 \%$ \\
\hline
\end{tabular}




\begin{tabular}{|c|l|c|c|c|c|}
\hline 4 & $\begin{array}{l}\text { Tertib dalam } \\
\text { mengikuti } \\
\text { pembelajaran }\end{array}$ & $13.6 \%$ & $27.2 \%$ & $45.5 \%$ & $31.9 \%$ \\
\hline \multicolumn{2}{|l|}{ Rata-Rata } & $11.4 \%$ & $26.1 \%$ & $51.1 \%$ & $39,7 \%$ \\
\hline
\end{tabular}

Dari data tabel diatas dapat disimpulkan bahwa tingkat kedisiplinan anak secara keseluruhan mengalami peningkatan sebesar 39,9\%.

\section{Refleksi}

Refleksi ini dilakukan untuk mengetahui kekurangan-kekurang dari penelitian yang dilakukan agar dapat memperbaikinya pada siklus berikutnya.

Pada kegiatan Pra tindakan tingkat kedisiplinan anak masih kurang dari yang diharapkan, metode dan media yang digunakan juga belum membuahkan hasil yang maksimal, sehingga perlu adanya metode atau media baru yang dapat meningkatkan kedisiplinan anak, dan digunakanlah pohon kedisiplinan pada siklus I.

Pada siklus I refleksi yang didapat yaitu berupa pengendalian anak-anak saat di kelas, pengelolaan kelas yang belum maksimal, dan pemberian informasi yang kurang diperhatikan oleh anak. Refleksi tersebut menjadi bahan perbaikan pada siklus II yakni mengelola kelas dengan baik, memberikan penjelasan yang detail dan mengulang pertanyaan kepada anak agar lebih faham. Guru juga menempelkan nomor pada pohon sebagai motivasi belajar anak, agar anak lebih semangat saat menyelesaikan tugas dan fokus pada tuganya sendiri.

Pada Siklus II perbaikan-perbaikan sebelumnya telah dilakukan. Secara umum permasalahn-permasalah kedisiplinan yang menjadi kendala pembelajaran pada siklus II ini sudah teratasi dengan baik. Guru dapat mengarahkan anak untuk bersikap lebih disiplin dengan baik, guru juga dapat membangun antusiasme anak menggunakan Pohon Kedisiplinan dalam kegiatan pembelajaran. Partisipasi anak dalam kegiatan perbaikan pembelajaran pada siklus II meningkat. Hal ini berpengaruh pada hasil yang ingin dicapai yaitu meningkatnya sikap kesdisiplinan anak.

\section{Kesimpulan}

Peningkatan karakter disiplin anak melalui Pohon Kedisiplinan di TK Islam Kreatif Keluarga Ceria tahun ajaran 2018/2019. Dari penelitian yang telah dilakukan dapat disimpulkan bahwa peningkatan karakter disiplin anak melalui pohon kedisiplinan di TK 
Islam Kreatif Keluarga Ceria sebesar 39,7\% dengan rincian data peningkatan sebagai berikut:

a. Pada indikator pertama yaitu masuk kelas tepat waktu mencapai peningkatan sebesar $54,4 \%$

b. Pada indikator kedua yaitu mengerjakan tugas dengan baik mencapai peningkatan sebesar $31,9 \%$

c. Pada indikator ketiga yaitu menyelesaikan tugas tepat waktu mencapai peningkatan sebesar $40,9 \%$

d. Pada indikator ke empat yaitu tertib dalam mengikuti pembelajaran mencapai peningkatan sebesar $31,9 \%$

\section{Daftar Pustaka}

'Ulwan, Abdullah Nashih, Pendidikan Anak Dalam Islam, Solo : Insan Kamil, 2015

Arismantoro, Tinjauan Berbagai Aspek Character Building, Yogyakarta: Tiara Wacana, 2008

Departemen Pendidikan Nasional, Kamus Bahasa Indonesia, Jakarta: Pusat Bahasa, 2008

El-Khuluqo, Ihsana, Manajemen PAUD (Pendidikan Anak Usia Dini): Pendidikan Taman Kebidupan Anak, Yogyakarta: Pustaka Pelajar, 2015

Gupte, Suraj, Panduan Perawatan Anak, Jakarta : Pustaka Populer Obor, 2014

Hasanah, Hetti Nurjami'atun, "Peningkatan Kemampuan Sains Anak Usia Dini Melalui Metode Eksperimen (Tanaman Rimpang) Di Kelompok Bermain Islam Kreatif Keluarga Ceria Beran Tridadi Sleman",Skripsi, Program studi Pendidikan Islam Anak Usia Dini (PIAUD) STPI Bina Insan Mulia Yogyakarta, 2017

John, Eltin, "Upaya Meningkatkan Kedisiplinan Anak di Kelas melalui Cerita", Jurnal Pendidikan Penabur, No.16/Tahun ke-1,. Jakarta : BPK Penabur, 2011

Listyarti, Retno, Pendidikan Karekter dlam Metode Aktif, Inovatif, \& kreatif, Jakarta : Erlangga, 2012

Majid, Abdul, Pendidikan Karakter Prespektif Islam, Bandung: Rosdakarya, 2012

Maksudin, Pendidikan Karakter Nondikotomik, Yogyakarta: Pustaka Pelajar, 2013

Ma'sumah, Siti, “Pengarub Disiplin Belajar Terhadap Prestasi Siswa Kelas IV”,Skripsi. Universitas Negri Semarang, 2015

Moleong, Lexy J, Metodologi Penelitian Kualitatif, Bandung: Rosda, 2012

Mudlofir, Ali, "Pendidikan Karakter :Konsep Aktualisasinya dalam Pendidikan Islam". Jurnal Pendidikan Islam, Vol. 7 Nomor 2. Surabaya : Nadwa | IAIN Walisongo, 2013 
Mufidah, Umri, "Efektivitas Pemberian reward melalui metode token ekonomi untuk meningkatkan kedisiplinan anak usia dini", Indonesian Journal of Early ChildhoodEducation Studies, No.1, Vol.2. FIP UNNES, 2012

Musbikin, Imam, Mengapa ya Anakku Kok Suka Berbohong? Yogyakarta: Diva Press, 2009

Mushoffa, Aziz, Aku Anak Hebat Bukan Anak Nakal, Yogyakarta: Diva Press, 2009

Naim, Ngainun, Character Building,Yogyakarta :Ar-Ruzz Media, 2012

Purwanto, Setyoadi, Pendidikan Karakter melalui Seni, Yogyakarta: Pustaka Pelajar, 2016

Rahayuningsih, Dwi Puji, "Peningkatan Kemampuan Disiplin Pada Anak Usia Dini Melalui Kegiatan Bermain Peran di RA Muslimat NU Mafatibul Islamiyah" Jurnal Ilmiah, No. 1, Vol 1. PG-PAUD IKIP Veteran, 2012

Rimm, Silvia, Raising Preschoolers Parenting For Today, Jakarta: Gramedia Pustaka, 2003

Sudewo, Erie, Character Building, Jakarta: Republika, 2011

Sudijono, Anas, Pengantar Evaluasi Pendidikan, Bandung: Raja Grafindo, 2011

Sugiyono, Metode Penelitian Pendidikan, Bandung: Alfabeta, 2014

Suyadi, MaulidyaUlfa, KonsepDasar PAUD, Bandung :Rosdakarya, 2013

Suyadi, Penelitian Tindakan Kelas (PTK) dan Penelitian Tindakan Sekolah (PTS), Yogyakarta: ANDI OFFSET, 2012

2014

,Teori Pembelajaran Anak Usia Dini Dalam Kajian Neurosains, Bandung : Rosdakarya,

Tum, "Meningkatkan Kedisiplinana anak melalui metode pemberian tugas pada kelompok B di TK Bungamputi”, Skripsi, Program Studi PGPAUD, Jurusan Ilmu Pendidikan, Fakultas Ilmu Keguruan dan Ilmu Pendidikan Universitas Tadulako, 2013.

Umayanti, Khikmah, "Upaya Meningkatkan Kreativitas AUD melalui Media Tangram", Skripsi,Program Studi Pendidikan Guru Raudhotul AtfalSTPI Bina Insan Mulia Yogyakarta, 2016

Widowati, Nurcahyani Desi, "Hubungan antara pola asuh orang tua, motivasi belajar, kedewasaan dan kedisiplinan siswa dengan prestasi belajar sosiologi siswa kelas XI SMA Negeri 1 sidoharjo wonogirn" Jurnal Ilmiah Pendidikan Sosial, Vol 3, No. 2, Surakarta : FKIP.UNS, 2013

Zubaedi, Desain Pendidikan Karakter : Konsepsi dan aplikasinya dalam lembaga pendidikan. Jakarta: Kencana, 2011 